\title{
Antioxidant effect of cathodic water on seeds
}

\author{
Marcela Andreotti Ricaldoni ${ }^{1}$ (D) Sttela Dellyzete Veiga Franco da Rosa ${ }^{2 *}$ (D) \\ Franciane Pinheiro Cardoso ${ }^{3}$ (D) Madeleine Alves de Figueiredo ${ }^{1}$ (D) \\ Amanda Lima Vilela ${ }^{1}$ (D) Stefânia Vilas Boas Coelho ${ }^{1}$ iD Nathália Aparecida Bragança Fávaris ${ }^{1}$ (D)
}

${ }^{1}$ Departamento de Agricultura, Universidade Federal de Lavras (UFLA), Lavras, MG, Brasil.

${ }^{2}$ Empresa Brasileira de Pesquisa Agropecuária, Embrapa Café, Parque Estação Biológica (PqEB), 70770-901, Brasília, DF, Brasil. E-mail: sttela.rosa@embrapa.br. "Corresponding author.

${ }^{3}$ Departamento de Química, Universidade Federal de Lavras (UFLA), Lavras, MG, Brasil.

ABSTRACT: Recalcitrant and intermediate seeds have limitations regarding conservation because of their sensitivity to desiccation and response to storage. Establishing a method for seed storage is difficult because these seeds deteriorate rapidly, which can intensify production of reactive oxygen species that cause lethal oxidative damage to plant tissues. Orthodox seeds, which have greater tolerance to desiccation and storage, are also subject to deterioration processes, in degrees that vary according to the species. Damage caused by harmful levels of free radicals can be mitigated by the action of endogenous or exogenous antioxidants. Recent studies have led to new technologies for protection coming from antioxidants, one of which is cathodic protection. This is a technique with promising results in recalcitrant species, as well as in other living organisms. This paper reviews results regarding the antioxidant activity of cathodic water produced from electrolysis of a calcium chloride and magnesium chloride solution.

Key words: reactive oxygen species, seed deterioration, free radicals.

Ação antioxidante da água catódica em sementes

RESUMO: As sementes recalcitrantes e intermediárias apresentam limitações com relação à conservação, devido a sua sensibilidade à dessecação e ao comportamento durante o armazenamento. Uma dificuldade no estabelecimento de metodologias para o armazenamento dessas sementes é devido à rápida deterioração, em que atuam processos que podem potencializar a produção de espécies reativas de oxigênio, causando danos oxidativos letais aos tecidos vegetais. Sementes ortodoxas, as quais apresentam maior tolerância à dessecação e ao armazenamento, também sofrem a ação dos processos deteriorativos, em graus variáveis com as espécies. Os danos causados por níveis nocivos de radicais livres podem ser amenizados pela ação de antioxidantes endógenos ou exógenos. Resultados de pesquisas recentes têm possibilitado novas tecnologias de proteção antioxidativa, sendo a proteção catódica uma técnica promissora e com resultados relevantes em espécies sensíveis à dessecação e em outros organismos vivos. Neste trabalho é apresentada uma revisão sobre a ação antioxidante da água catódica, produzida a partir da eletrólise de uma solução contendo cloreto de cálcio e cloreto de magnésio.

Palavras-chave: espécies reativas de oxigênio, deterioração de sementes, radicais livres.

\section{INTRODUCTION}

Deterioration of seeds of all species during storage is associated with the loss and oxidation of antioxidant systems (DUSSERT et al., 2006), which may lead to generation of reactive oxygen species (ROS), free radicals, peroxidation of compounds, enzyme inactivation, and loss of viability (BENSON
\& BREMNER, 2004; ROACH et al., 2008; WHITAKER et al., 2010; BERJAK et al., 2011).

Reactive species are chemical compounds, most of which have high reactivity. According to MAGDER (2006) and CAROCHO \& FERREIRA (2013), reactive species can be divided into two groups: free radicals and non-radical compounds. In general, free radicals are atoms or molecules that have 
at least one unpaired electron in their outer shells, which makes electron transfer with neighboring molecules possible. Thus, free radicals can act as electron acceptors or donors, creating changes in the surrounding molecular environment. Non-radical compounds, such as hydrogen peroxide $\left(\mathrm{H}_{2} \mathrm{O}_{2}\right)$, for their part, do not have free electrons, but can also react with surrounding molecules. Therefore, every free radical is a reactive oxygen species, since it has unpaired electrons; yet, not every reactive oxygen species has an unpaired electron. There are reactive species in other atoms, as for example reactive nitrogen species, but in this review, reactive oxygen species will be highlighted, due to their greater importance in seeds.

Deterioration processes in seeds, especially during post-harvest operations, result in production of these reactive oxygen species, and they may cause lethal oxidative damage to plant tissues. Recent studies have shown that loss of seed viability during drying goes along with an increase in ROS and with lipid peroxidation (OLIVEIRA et al., 2011). The ROS are partially reduced forms of atmospheric oxygen $\left(\mathrm{O}_{2}\right)$; these molecules are able to oxidize various cell components and may lead to cell death. According to the authors, they interfere in DNA and RNA; and consequently, in the synthesis of enzymes associated with seed quality, such as superoxide dismutase, ascorbate peroxidase, dehydroascorbate reductase, monodehydroascorbate reductase, glutathione reductase, glutathione peroxidase, and guaiacol peroxidase.

A free radical is any molecule that contains one or more unpaired electrons; this includes the superoxide radical $\left(\mathrm{O}_{2}^{-*}\right)$, hydroperoxyl radical $\left(\mathrm{HO}_{2}{ }^{\circ}\right)$, singlet oxygen $\left({ }^{1} \mathrm{O}_{2}\right)$, and hydroxyl radical $(\mathrm{OH} \bullet)$ (FERREIRA \& MATSUBARA, 1997). These molecules are able to react with compounds of membranes, nucleic acids, proteins, enzymes, lipids, and other molecules, altering the normal biological functions of the cells, which may lead to their deterioration, aging, and even cell death. Many of these reactive agents are involved in normal cell functions, but some are more highly produced under specific conditions.

Among reactive species, hydrogen peroxide $\left(\mathrm{H}_{2} \mathrm{O}_{2}\right)$, a natural metabolite present in many organisms, can be converted through catalysis into a hydroxyl radical $(\mathrm{OH} \bullet)$, which is very reactive, with reactivity only inferior to that of fluorine. It is unstable and is of extreme danger from a biological perspective (MATTOS, 2003). The $\mathrm{OH} \bullet$ radical reacts immediately after its formation with any biological molecule around it, and due to its very short half-life, it is unlikely to be sequestered in vivo. In addition, unlike hydrogen peroxide and the superoxide anion, there are no enzymatic defenses against this radical (RABÊLO et al., 2010).

Biochemical and physiological aspects of the performance of intermediate seeds, which are more subject to deterioration during storage, such as coffee seeds, were investigated by DUSSERT et al. (2006). These authors evaluated the effects of drying and of storage on the viability of seeds and the changes in the content of lipids, sugars, and antioxidant compounds. They concluded that slow drying of coffee seeds induced significant reduction in the concentrations of two main antioxidants, glutathione and ascorbate, and an increase in free fatty acid content, regardless of the moisture content in the seeds. DUSSERT et al. (2006) observed that seeds stored at $81 \%$ moisture content at $20{ }^{\circ} \mathrm{C}$ very quickly lost their viability, whereas seeds stored at $45 \%$ moisture content at $5{ }^{\circ} \mathrm{C}$ did not exhibit a decline in viability.

Among the chemical components that protect seeds from the effects of ROS and;consequently, from the deterioration process during storage are antioxidants, which eliminate toxic substances resulting from reactions mediated by free radicals. Stress situations, such as removal of water from cells, induce oxidative processes, with consequent production of free radicals. The capacity of seeds to tolerate desiccation may also be related to their capacity in removing activated oxygen species so as to avoid deleterious events, such as lipid peroxidation caused by these compounds (HENDRY, 1993; VERTUCCI \& FARRANT, 1995).

The role of reactive oxygen species has been documented in the literature, indicating that they are at the center of damage associated with dehydration and cell deterioration. Nevertheless, production of free radicals is part of plant metabolism and is also associated with plant development events, such as seed germination, with physiological processes involved in energy production, regulation of seedling size, intracellular signaling, and synthesis of important substances, such as hormones and enzymes (BERJAK et al., 2011). To counterbalance this production and its potential negative effects, the organism has antioxidant systems.

Two approaches for protection against the harmful effects of ROS are performing treatments to reduce or inhibit their production, and exogenous application of antioxidants that can act directly on them and even improve endogenous 
antioxidant activity. To inhibit or reduce formation of the hydroxyl radical, it is important to understand how this radical may be produced. The following are three main mechanisms for production of the radical (KEHRER, 2000; BARREIROS et al., 2006; BERJAK et al., 2011):

Peroxide reaction with transition metals (Fenton reaction)

$\mathrm{H}_{2} \mathrm{O}_{2}+\mathrm{Fe}^{2+} \diamond \mathrm{Fe}^{3+}+\mathrm{OH}^{-}+\mathrm{OH} \bullet$

Homolysis of water through exposure to ionizing radiation

$\mathrm{H}_{2} \mathrm{O}+\mathrm{Luz} \mathrm{UV} \diamond \mathrm{OH} \bullet+\mathrm{H} \bullet$

Interaction of peroxide with superoxide.

Haber-Weiss reaction

$\mathrm{H}_{2} \mathrm{O}_{2}+\mathrm{O}_{2} \bullet \bullet 2 \mathrm{OH} \bullet+\mathrm{O}_{2}$

Strategies for inhibiting or decreasing the formation of the hydroxyl radical in the system include the following:

In situations in which the reaction represented by Equation 1 can occur (peroxide reaction with transition metals - Fenton type), it would be important to ensure the absence of any $\mathrm{Fe}^{2+}$ that triggers the Fenton reaction, which forms hydroxyl radicals. $\mathrm{H}_{2} \mathrm{O}_{2}+\mathrm{Fe}^{2+}$ the reaction does not occur.

$\mathrm{H}_{2} \mathrm{O}_{2}+\mathrm{Fe}^{2+} \rightarrow$ the reaction does not occur.

Formation of the hydroxyl radical, with water as the starting reagent, occurs through simple contact with UV light (Equation 2), which has enough energy to break down the water molecule, forming this radical. Thus, eliminating any source of UV light in the system would be a manner of impeding formation of the hydroxyl radical, since water molecules are abundant in the system.

And, finally, it would be important to inhibit the formation of superoxide in solution (Equation 3). Superoxide is formed by reduction of the oxygen molecule $\left(\mathrm{O}_{2}\right)$ by an electron:

$\mathrm{O}_{2}+\mathrm{e} \diamond \mathrm{O}_{2}-\bullet$

Detection of the activity or of the presence of ROS removing enzymatic systems is used as a marker of deterioration, and its correlation with physiological performance allows better understanding of loss of seed quality. In coffee seeds, for example, this association between physiological quality and antioxidant enzyme activity was reported in several studies (COELHO et al., 2015 and 2018; SAATH, R. et al., 2014). Diverse antioxidant enzymes are detected in plant cells, including superoxide dismutase (SOD), catalases (CATs), ascorbate peroxidase (APX), monodehydroascorbate and dehydroascorbate reductase, glutathione reductase (GR), glutathione-S-transferases (GST), and peroxidase (PO) (KRANNER \& BIRTIC, 2005).
Superoxide dismutation is a reaction that has been extensively studied, because it allows the formation of peroxide, which constitutes an extremely deleterious reactive oxygen species. Hydrogen peroxide $\left(\mathrm{H}_{2} \mathrm{O}_{2}\right)$ can be regarded as not very reactive toward organic molecules in the absence of transition metals. Nevertheless, it plays an important role in oxidative stress since it can easily pass through cell membranes and generate the hydroxyl radical $(\mathrm{OH} \bullet) \cdot \mathrm{H}_{2} \mathrm{O}_{2}$ only oxidizes proteins that have residues of methionine or very reactive thiol groups, e.g., glutathione. Thus, it is highly toxic for cells, and this toxicity can be increased from ten to 1000 times in the presence of iron (FERREIRA; MATSUBARA, 1997).

The dismutation reaction can occur in the presence of the superoxide dismutase enzyme, according to the following semi-reactions (BARREIROS et al., 2006):

$$
\begin{gathered}
\mathrm{M}^{(\mathrm{n}+1)+}-\mathrm{SOD}+\mathrm{O}_{2}-\rightarrow \mathrm{Mn}^{+}-\mathrm{SOD}+\mathrm{O}_{2} . \\
\mathrm{Mn}^{+}-\mathrm{SOD}+\mathrm{O}_{2}-+2 \mathrm{H}^{+} \rightarrow \mathrm{M}^{(\mathrm{n}+1)+}-\mathrm{SOD}+\mathrm{H}_{2} \mathrm{O}_{2} . \\
\text { where } \mathrm{M}=\text { redox center. }
\end{gathered}
$$

In addition to the action of antioxidant enzymes and the activity of other endogenous and exogenous antioxidants, another form of attack against ROS has been investigated in live organisms, in which peroxidation can be avoided, in part, through supplying electrons that react with these reactive agents. This is the basis of cathodic protection, which began to be studied in the 1970s and is still the focus of more recent studies (BERJAK et al., 2011).

According to HANAOKA (2001), the use of a $\mathrm{NaOH}$ base solution in cathodic water, associated with an antioxidant such as ascorbic acid, accentuates the antioxidant power of the acid, which becomes a better proton $\left(\mathrm{H}^{+}\right)$donor, performing dismutation of the superoxide in peroxide, as shown in figure 1.

\section{Cathodic protection against the attack of reactive oxygen species}

The use of cathodic water, generated by electrolysis of a solution containing calcium chloride and magnesium chloride has exhibited antioxidant effects (SHIRAHATA et al., 1997; HANAOKA, 2001; HANAOKA et al., 2004a; HIRAOKA et al., 2004). This cathodic fraction has great potential for improving responses to stress related to procedures that can deteriorate plant materials (BERJAK et al., 2011).

Inhibition of the formation of superoxide has been studied and reported by some authors (GILL \& TUTEJA, 2010; TATONE et al., 2010). One of the reports that has shown effectiveness in dismutation 


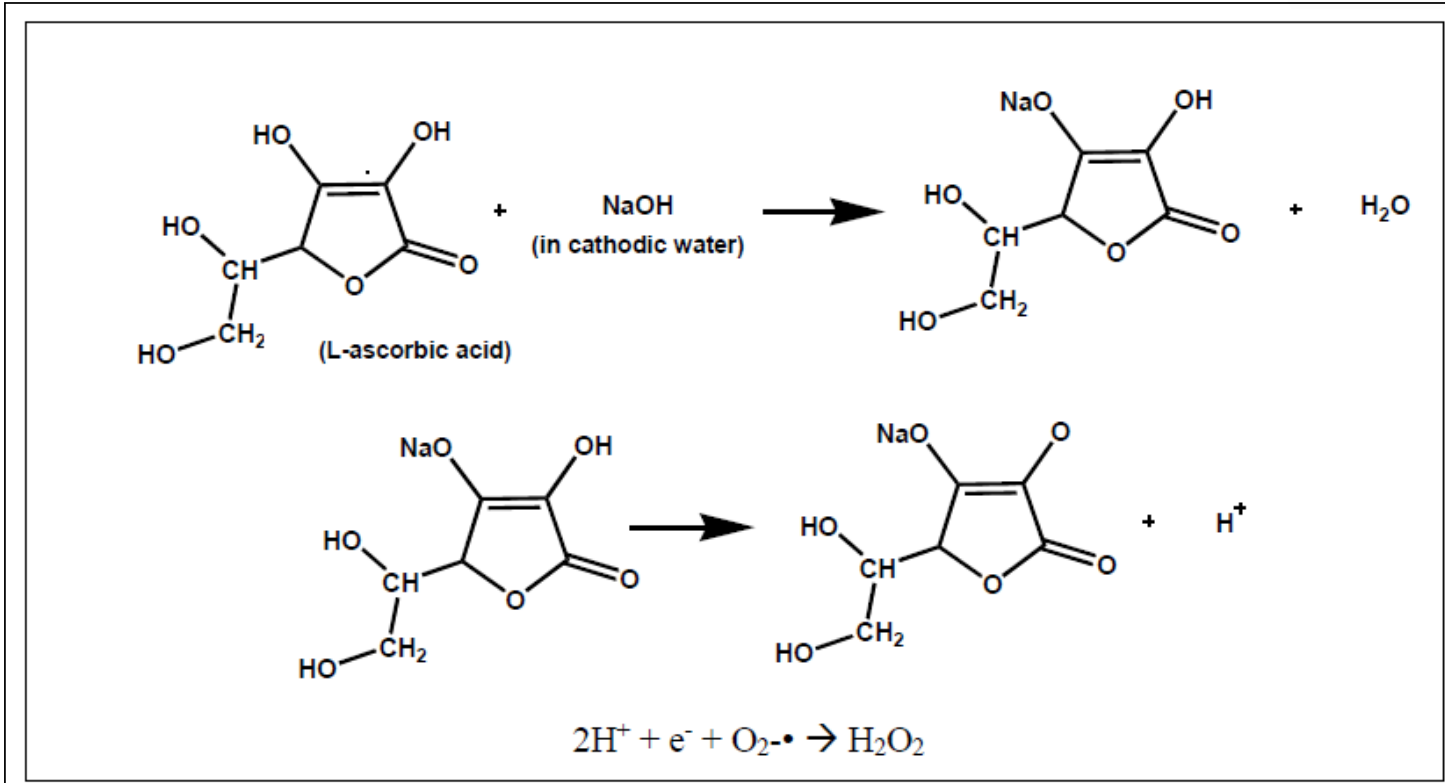

Figure $1-\mathrm{NaOH}$ solution in cathodic water, associated with ascorbic acid performing dismutation of the superoxide in hydrogen peroxide.

of the superoxide in peroxide is the use of a $\mathrm{NaOH}$ base solution in cathodic water, associated with an antioxidant such as ascorbic acid, accentuating the antioxidant power of the acid, which becomes a better proton $\left(\mathrm{H}^{+}\right)$donor. The $\mathrm{H}^{+}$released in the cathodic water with $\mathrm{NaOH}$ reaction reduces the superoxide to hydrogen peroxide (HANAOKA, 2001).

SHIRAHATA et al. (1997) characterized cathodic water by making use of the principle of electrolysis of Michael Faraday, postulated in the period of 1791-1867. Under this principle, the process of reduction on the cathode and oxidation on the anode occurs, and this is the basis of cathodic protection. The dissociation of $\mathrm{H}_{2} \mathrm{O}$ produces $\mathrm{H}_{2}$ and $\mathrm{O}_{2}$, as well as the ions $\mathrm{H}^{+}$and $\mathrm{OH}^{-}$, according to the following equations: Water electrolysis

Overall reaction: $\mathrm{H}_{2} \mathrm{O}(\mathrm{l}) \diamond \mathrm{H}_{2}(\mathrm{~g})+\mathrm{O}_{2}(\mathrm{~g})$

Anode (oxidation reaction): $2 \mathrm{H}_{2} \mathrm{O}(\mathrm{l}) \diamond \mathrm{O}_{2}(\mathrm{~g})+$ $4 \mathrm{H}^{+}(\mathrm{aq})+4 \mathrm{e}^{-}$

Cathode (reduction reaction): $4 \mathrm{H}_{2} \mathrm{O}(\mathrm{l})+4 \mathrm{e}^{-} \diamond 2 \mathrm{H}_{2}(\mathrm{~g})$

$+4 \mathrm{OH}^{-}(\mathrm{aq})$

$6 \mathrm{H}_{2} \mathrm{O}(\mathrm{l}) \diamond \uparrow \mathrm{O}_{2}(\mathrm{~g})+4 \mathrm{H}^{+}(\mathrm{aq})+2 \uparrow \mathrm{H}_{2}(\mathrm{~g})+4 \mathrm{OH}^{-}(\mathrm{aq})$ (10)

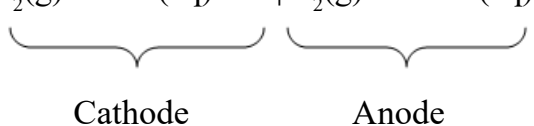

The studies of SHIRAHATA et al. (1997) also showed that cathodic water eliminates the ROS and protects DNA against damage by free radicals. On the cathode, the $\mathrm{H}^{+}$ions gain electrons to be transformed into atomic active hydrogens $(\mathrm{H})$. Atomic active hydrogens have high reduction potential and are thus transformed into hydrogen molecules $\left(\mathrm{H}_{2}\right)$, which are chemically inert at ambient temperature. At the anode, the $\mathrm{OH}^{-}$ions lose electrons to form $\mathrm{O}_{2}$. The alkaline cathodic water (reduced water) is abundant in dissolved hydrogen, while acidic anodic water (oxidized water) is abundant in dissolved oxygen.

\section{Effects of cathodic protection against damage from reactive oxygen species in seeds \\ In previous studies, cathodic protection} was analyzed and its antioxidant activity investigated in living organisms. Studies on cathodic protection were based on treatment against aging of mice (MOLNAR, 1973) regarding the beneficial effects of treatment of diverse diseases and techniques against metal corrosion, in which the application of negative electric potential (cathodic protection) brought about reduction in ROS attack. In these studies, there was the attempt to reduce the attack of reactive agents not through supplying antioxidants in the diet but by maintaining the mice in cages with a negative charge, applied in a manner analogous to the technique of cathodic protection of metals against corrosion. 
MOLNAR (1973) reported that the mean and maximum life expectancy of mice maintained in cages to which negative potentials were applied were $25 \%$ and $32 \%$ greater, respectively, than those maintained in cages charged with positive potential. In addition, the white blood cell count of the mice maintained at a negative potential was nearly two times greater than that of the control mice placed in cages without potential, and more than two times greater compared to those maintained in cages with positive potential. It was also suggested that the negative charge led to relative protection against the effects of radiation.

The study of BERJAK (1978) showed an increase in viability of artificially aged maize seeds kept in a negatively charged electrical conductor. The use of a static electric charge of $-300 \mathrm{~V}$ during and after the seed aging period led to a greater percentage of germination and greater growth of maize seedlings. In this study, ultrastructural analysis, made by electron microscopy, showed that in seeds under cathodic protection, significant subcellular improvement occurred in relation to untreated seeds. The benefits of cathodic protection, according to the authors, are not restricted to the surface that covers the seeds. Microscopic examination of the pericarps of maize seeds showed changes in the apoplast through analysis of the three phases of peroxidation of membrane components, i.e., deterioration of the cytoplasm mainly affecting the mitochondria, damage to the membranes, with loss of subcellular control, and the third stage with cell lysis or rupture and dissolution of the membrane.

Another study was developed by PAMMENTER et al. (1974), in which maize seeds were subjected to artificial aging treatment and to cathodic protection, and those seed exhibited a significant reduction in loss of viability. In the electrical conductivity test, the seeds had considerably lower membrane degradation than the seeds that were not protected. In addition, after 10 days of accelerated aging, the percentage of chromosome aberrations was three times less in the protected seeds. The authors concluded that cathode protection reduced the attack of free radicals on biological macromolecules, presumably because it functions as a source of electrons, which react with these free radicals.

Studies on cryopreservation of embryonic axes of recalcitrant species (BERJAK et al., 2011) showed that the use of cathodic water led to improvement in oxidative damage related to the different steps of the process. In this case, the action of cathodic water was most likely related to stimulating endogenous antioxidant activity than to directly eliminating the reactive species.

NAIDOO et al. (2016) investigated methods of cryopreservation of primary and secondary explants coming from recalcitrant seeds of Trichilia dregeana. The authors examined the effectiveness of known chemical antioxidants and new means of cathodic protection (PAMMENTER et al., 1974; BERJAK et al., 2011) in the aqueous and dry phase in each step of cryopreservation so as to avoid the destructive effects caused by reactive oxygen species during the cryogenic process. PAMMENTER et al., 1974 and BERJAK et al., 2011 observed a positive effect in use of cathodic protection, with lower quantification of ROS during the steps of cryopreservation and a higher survival number and development of the excised embryonic axes. According to these authors, results help in understanding oxidative stress, associated with every cryogenic procedure, and the positive effect of cathodic water on advancing cryopreservation of recalcitrant seeds such as those of Trichilia dregeana.

GONDWE et al. (2016) studied the effect of physiological conditioning (priming) with subsequently storage of seeds of Pisum sativum (pea), Cucurbita maxima (squash), and Lycopersicon esculentum (tomato). The authors observed that the priming treatment with cathodic water improved germination of the seeds of the three species studied, especially pea and squash seeds, whether stored or not, as well as seed vigor, which was determined by measurement of the shoots and roots of the germinated seeds and by estimation of germination time by the method proposed by ELLIS \& ROBERTS (1981). In addition, they observed longer roots for the seeds under priming with cathodic water than under any other priming solution used. The authors concluded that the strong antioxidant properties of cathodic water suggested potential for facilitating both repair of and protection against damage caused by storage.

Positive effects of cathodic water were also reported in studies on stresses arising from the processes of drying, cooling, and reheating on the physiological, biochemical, and ultrastructural quality of Coffea arabica L. seeds (FIGUEIREDO, 2016), in which there was recovery from oxidative damage caused during cryopreservation. In that study, the treatment of soaking seeds in cathodic water for 60 minutes after rapid drying of the seeds to $17 \%$ moisture contributed to maintaining or reestablishing cell integrity, preventing loss of cell content. In addition, expression of the isocitrate lyase enzyme was lower in the slowly dried coffee 
seeds, which had physiological quality inferior to those under rapid drying.

According to SHIRAHATA et al. (1997; 1999), cathodic water can penetrate all membranes, in all parts of the body, including the blood-brain barrier, and may be considered a powerful and ideal antioxidant in living organisms, eliminating ROS, protecting DNA and RNA molecules. Besides the cathodic water have ability to suppress the growth of human cancer cells and glucose consumption by the cells of mice that had diabetes. SHIRAHATA et al. (1999) also declared that active hydrogen may be present in various natural or artificial aqueous media, as cited by RICALDONI (2016).

After these publications of SHIRAHATA (1997; 1999), some companies, such as Nihon Trim (Osaka, Japan), the Water Institute (Atarashii Mizuno Kai) (Tokyo, Japan), and Hita Tenryo Sui Kabushikigaisha (Oita, Japan), among others, have developed and sold various products related to the production of cathodic water for health, announcing that such products produce strong "cleaners" of free radicals from the body (HIRAOKA et al., 2004).

Cathodic water can be easily produced, according to the method adapted from BERJAK et al. (2011): a solution containing, as electrolytes, 0.5 $\mathrm{mM} \mathrm{CaCl} 2.2 \mathrm{H}_{2} \mathrm{O}$ and $0.5 \mathrm{mM} \mathrm{MgCl} \cdot 6 \mathrm{H}_{2} \mathrm{O}$ should be divided and placed in a horizontal tub suitable for the electrophoretic process, and the circuit should be completed using a salt bridge with an agar base containing potassium chloride. The solution should be electrolyzed applying a $60 \mathrm{~V}$ potential difference (Figure 2). Electrolysis is performed for one hour at ambient temperature, producing half the volume of anodic water (oxidized) abundant in dissolved oxygen, with acidic $\mathrm{pH}$ near 3-4, which may act as a decontaminant and, apparently, a powerful antimicrobial agent (HANAOKA et al., 2004b). And in the other half, cathodic (reduced) water is produced, with alkaline pH near 11-12, as shown in figure 3 .

Thus, the antioxidant effects of cathodic water, improving antioxidative reactions to different types of stresses on living organisms, are well documented in the literature (SHIRAHATA et al., 1997; HANAOKA, 2001; HANAOKA et al., 2004a; HIRAOKA et al., 2004; BERJAKet al, 2011; FIGUEIREDO, 2016; NAIDOO et al., 2016). Seed treatment, through immersion or soaking in cathodic water, can also improve physiological performance after the post-harvest procedures of processing, drying, and storage.

\section{CONCLUSION}

From analysis of the various studies, we concluded that cathodic water provides a non-toxic medium for improvement from oxidative damage related to stresses, structural impairment, and cell degradation. The cathodic (reduced) fraction obtained from hydrolysis of an aqueous solution of calcium

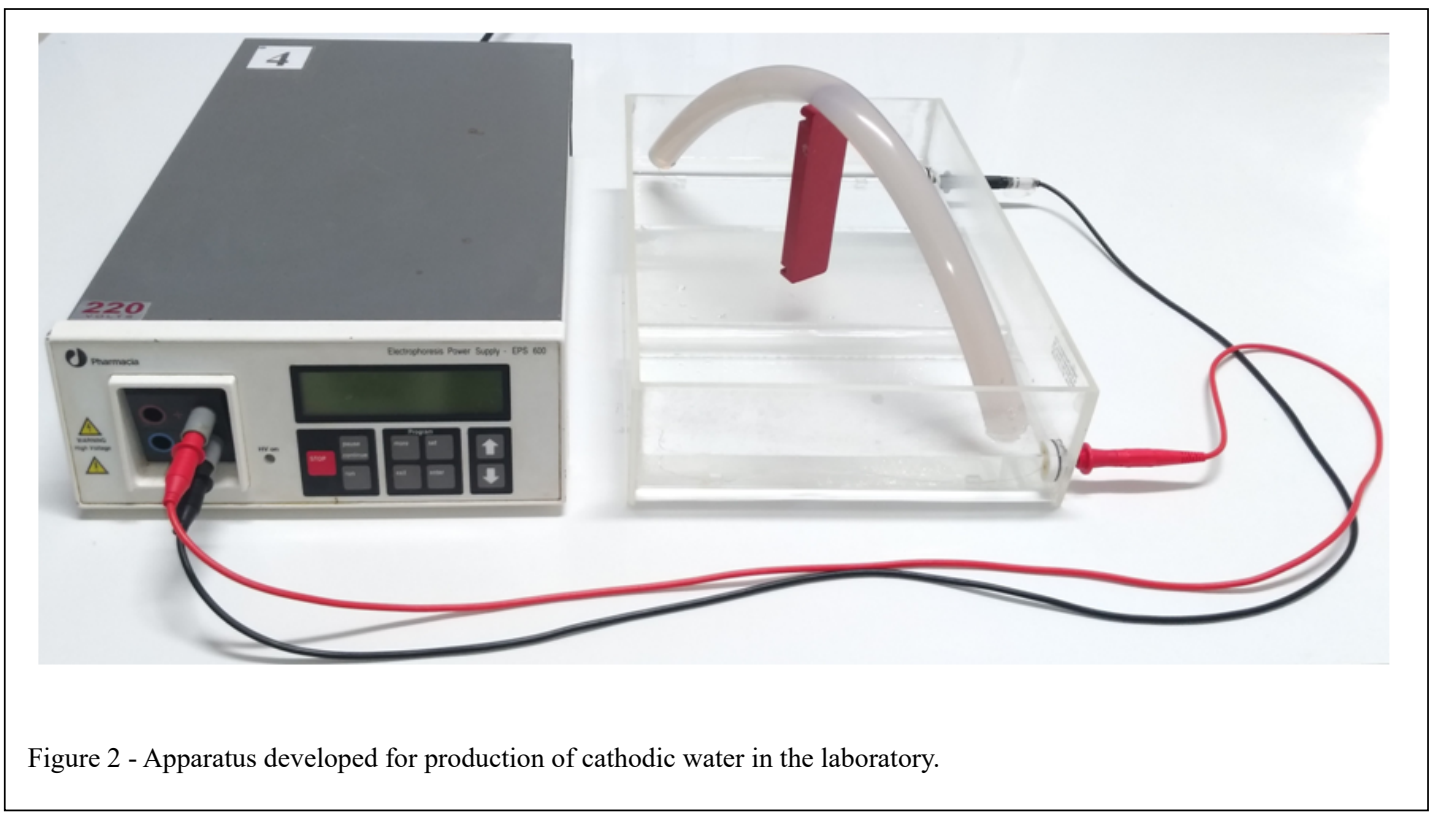

Ciência Rural, v.50, n.6, 2020. 


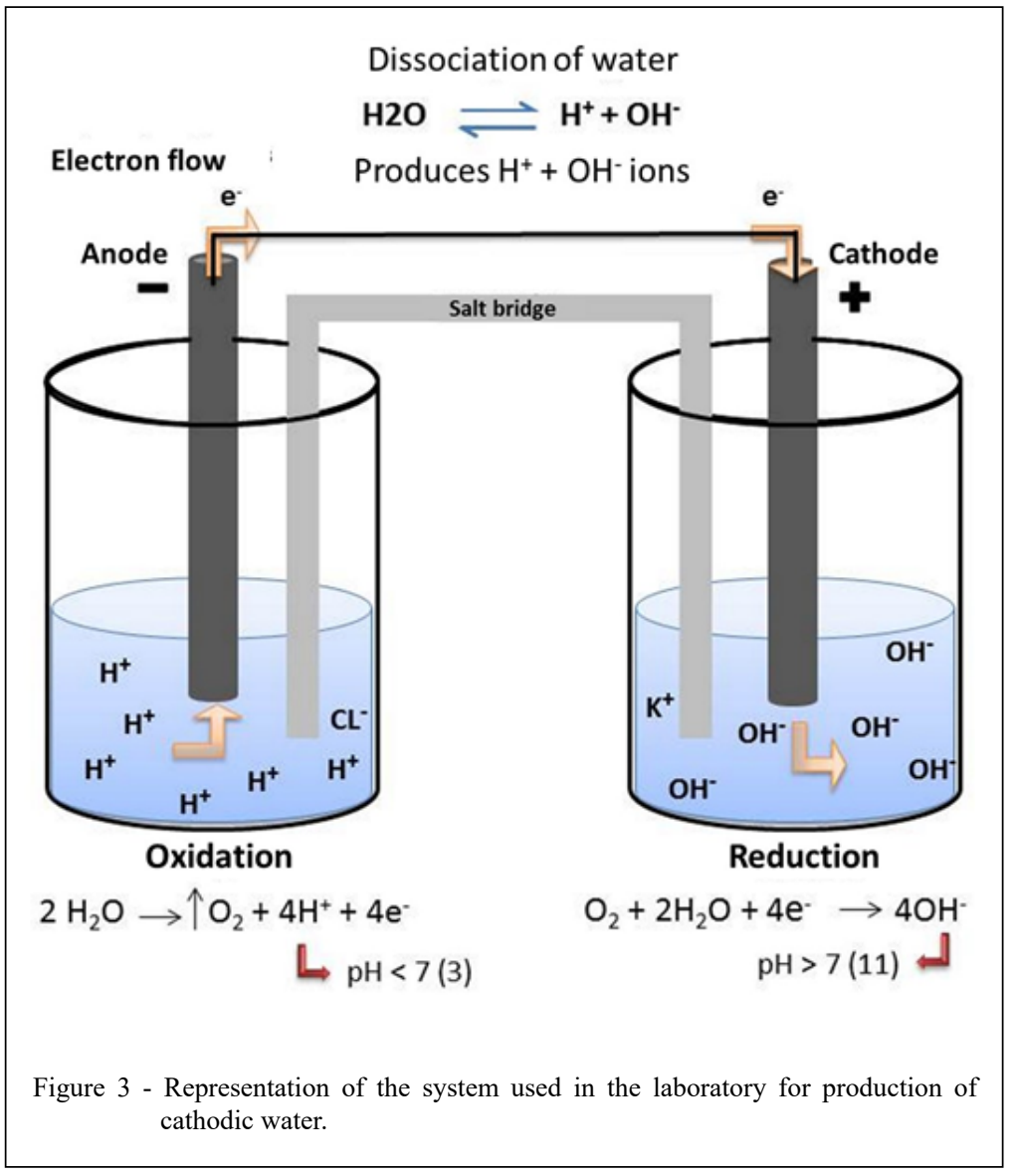

chloride and magnesium chloride has antioxidant properties with potential for enhancing the response of living organisms to oxidative stress arising from processes that can cause damage to plant materials. Thus, seeds of low physiological quality in the process of deterioration caused by different types of stresses may also show improvement in their physiological performance after treatment with cathodic water.

\section{ACKNOWLEDGMENTS}

Our thanks to the Coordenação de Aperfeiçoamento de Pessoal de Nível Superior (CAPES), the "Conselho Nacional de Desenvolvimento Científico e Tecnológico" (CNPq), the Empresa Brasileira de Pesquisa Agropecuária, Embrapa Café, and to Instituto Nacional de Ciência e Tecnologia do Café (INCT Café), for financial support or scholarships granted to the authors.

\section{DECLARATION OF CONFLICT OF} INTERESTS

The authors declare no conflict of interest. The founding sponsors had no role in the design of the study; in the collection, analyses, or interpretation of data; in the writing of the manuscript, and in the decision to publish the results.

\section{AUTHORS' CONTRIBUTIONS}

All authors contributed equally for the conception and writing of the manuscript. All authors critically revised the manuscript and approved of the final version.

\section{REFERENCES}

BARREIROS, A. L. B. S. et al. Oxidative stress: relation between generation of reactive species and organism defense. Química Nova, São Paulo, v.29, n.1, p.113-123, Jan. 2006. Available from: $<$ http://www.scielo.br/scielo.php?script=sci arttext\&pid=S010040422006000100021\&lng=pt\&nrm=iso\&tlng=pt> Accessed: Jun. 17, 2017. doi: 10.1590/S0100-40422006000100021.

BENSON, E. E.; BREMNER, D. Oxidative stress in the frozen plant: a free radical point of view. In: FULLER, B.J.; LANE, N.; BENSON, E.E. (Eds.). Life in the frozen state. 1st ed. Boca Raton: CRC Press, 2004, cap.6, p.205-241.

BERJAK, P. Viability extension and improvement of stored seeds. South African Journal of Science, Pretoria, v.74, n.10, p.365,

Ciência Rural, v.50, n.6, 2020. 
Oct. 1978. Available from: <http://journals.co.za/docserver/ fulltext/sajsci/74/10/6919.pdf?expires $=1528749362 \&$ id=id\&accn ame $=$ guest $\&$ checksum $=22$ B82B17847DCD9266853A97E7ED50 6A>. Accessed: Jun. 17, 2017.

BERJAK, P. et al. Cathodic amelioration of the adverse effects of oxidative stress accompanying procedures necessary for cryopreservation of embryonic axes of recalcitrant-seeded species. Seed Science Research, Wageningen, v.21, n.3, p.187-203, Sep. 2011. Available from: <https://www.cambridge.org/core/ journals/seed-science-research/article/cathodic-ameliorationof-the-adverse-effects-of-oxidative-stress-accompanyingprocedures-necessary-for-cryopreservation-of-embryonicaxes-of-recalcitrantseeded-species/C6BA89C00704F947F2 E67A0954060880>. Accessed: Mar. 23, 2017. doi: 10.1017/ S0960258511000110.

CAROCHO, M.; FERREIRA, I. C. F. R. A review on antioxidants, prooxidants and related controversy: Natural and synthetic compounds, screening and analysis methodologies and future perspectives. Food and Chemical Toxicology, v.51, p.15-25. 2013. Available from: <https://www.sciencedirect.com/science/ article/pii/S0278691512006941>. Acessed: Dec. 02, 2018. doi: 10.1016/j.fct.2012.09.021.

COELHO, S. V. B., et al. (2015). Physiological and biochemical changes in coffee seeds dried in silica gel and saturated salt solutions. Pesquisa Agropecuária Brasileira, 50, 483-491. Available from: <http://www.scielo.br/scielo.php?pid=S0100204X2015000600483\&script $=$ sci_abstract $>$. Acessed: Dec. 18, 2018. doi: 10.1590/S0100-204X2015000600007.

COELHO, S. V. B et al. Cryopreservation in Coffea canephora Pierre seeds: Slow and fast cooling. Ciência e Agrotecnologia, Lavras, v.42, n.6, p.588-597, Dec. 2018.

DUSSERT, S. et al. Oxidative stress, phospholipid loss and lipid hydrolysis during drying and storage of intermediate seeds. Physiologia Plantarum, Lund, v.127, n.2, p.192-204, Jun. 2006. Available from: <https://onlinelibrary.wiley.com/doi/abs/10.11 11/j.1399-3054.2006.00666.x>. Accessed: Mar 13, 2017. doi: 10.1111/j.1399-3054.2006.00666.x.

FERREIRA, A. L. A.; MATSUBARA L. S. Free radicals: concepts, related diseases, defense system, and oxidative stress. Revista da Associação Médica Brasileira, v.43, p.61-68, Mar. 1997. Available from: <http://www.scielo.br/pdf/cr/v40n4/ a519cr1730.pdf>. Acessed: Dec. 02, 2018. doi: 10.1590/S010442301997000100014.

FIGUEIREDO, M. A. Drying and cooling of Coffea arabica $\mathbf{L}$. seeds for cryopreservation. 2016. 198f. Tese (Doutorado em Fitotecnia) - Curso de Pós-Graduação em Fitotecnia, Universidade Federal de Lavras.

GILL, S. S.; TUTEJA, N.; Reactive oxygen species and antioxidant machinery in abiotic stress tolerance in crop plants. Plant Physiology and Biochemistry, Amsterdam, v.48, n.12, p.909930, Dec. 2010. Available from: $<$ https://www.sciencedirect.com/ science/article/pii/S0981942810001798?via\%3Dihub>. Accessed: Nov. 12, 2016. doi: 10.1016/j.plaphy.2010.08.016.

GONDWE, D. S. B. et al. Effect of priming with cathodic water and subsequent storage on invigoration of Pisum sativum, Cucurbita maxima and Lycopersicon esculentum seeds. Seed Science and Technology, v.4, n.2, p.370-381, July, 2016.
Available from: <https://www.ingentaconnect.com/contentone/ ista/sst/2016/00000044/00000002/art00011>. Accessed: Dec. 06, 2018. doi: 10.15258/sst.2016.44.2.09.

HANAOKA, K. Antioxidant effects of reduced water produced by electrolysis of sodium chloride solutions. Journal of Applied Electrochemistry, Springer, v.31, n.12, p.1307-1313, Dec. 2001. Available from: <https://link.springer.com/article/10.10 23\%2FA\%3A1013825009701>. Accessed: Mar. 12, 2017. doi: 10.1023/A:1013825009701.

HANAOKA, K. et al. The mechanism of enhanced antioxidant effects against superoxide anion radicals of reduced water produced by electrolysis. Biophysical Chemistry, Amsterdam, v.107, n.1, p.71-82, Jan. 2004a. Available from: $<$ https://www.sciencedirect. com/science/article/pii/S0301462203002497?via\%3Dihub>. Accessed: Dec. 15, 2016. doi: 10.1016/j.bpc.2003.08.007.

HANAOKA, K. et al. Studies on the properties and real existence of aqueous solution systems that are assumed to have antioxidant activities by the action of 'active hydrogen'. Journal of Health Science, Tokyo, v.50, n.5, p.456-465, June 2004b. Available from: $<$ https://www.jstage.jst.go.jp/article/jhs/50/5/50_5_456/_article>. Accessed: Jun. 26, 2017. doi: 10.1248/jhs.50.456.

HENDRY, G. A. F. Oxygen, free radical processes and seed longevity. Seed Science Research, Wageningen, v.3, n.3, p.141153, Sept. 1993. Available from: <https://www.cambridge. org/core/journals/seed-science-research/article/oxygen-freeradical-processes-and-seed-longevity/09475DC1AD3DD9FCF 273DF1BBC56A4A7>. Accessed: Mar. 15, 2017. doi: 10.1017/ S0960258500001720.

HIRAOKA, A. et al. Studies on the properties and real existence of aqueous solution systems that are assumed to have antioxidant activities by the action of 'active hydrogen'. Journal of Health Science, Tokyo, v.50, n.5, p.456-465, 2004. Available from: $<$ https://www.jstage.jst.go.jp/article/jhs/50/5/50_5_456/_article $>$. Accessed: Jun. 07, 2017. doi: 10.1248/jhs.50.45 $\overline{6}$.

KRANNER, I.; BIRTIC, S. A modulating role for antioxidants in desiccation tolerance. Integrative and Comparative Biology, McLean, v.45, n.5, p.734- 740, Nov. 2005. Available from: $<$ https:// academic.oup.com/icb/article/45/5/734/624391>. Accessed: Jun. 11, 2017. doi: $10.1093 / \mathrm{icb} / 45.5 .734$.

KEHRER, J. P. The Haber-Weiss reaction and mechanisms of toxicity. Toxicology, Hamburg, v.149, n.1, p.43-50, August 2000. Available from: <https://www.ncbi.nlm.nih.gov/ pubmed/10963860>. Accessed: May, 27, 2017. doi: 10.1016/ S0300-483X(00)00231-6.

MAGDER, S. Reactive oxygen species: toxic molecules or spark of life? Critical Care, 10, 208, 2006.

MATTOS, I. L. et al. Hydrogen peroxide: Importance and determination. Química Nova, v.26 n.3, p.373-380, Out. 2003. Available from: $<$ http://www.scielo.br/scielo.php?script $=$ sci arttext\&pid $=\mathrm{S} 0100-40422003000300015 \& 1 \mathrm{ng}=\mathrm{pt} \& \mathrm{nrm}=$ is o\&tlng=pt $>$. Accessed: Oct. 15, 2016. doi: 10.1590/S010040422003000300015 .

MOLNAR, K. MECH. Subbiological aspects of ageing and the concept of biological cathode protection. Mechanisms of Ageing and Development, Athens, v.1, n.5, p.319-326, Mar. 1973. Available from: <https:/www.sciencedirect.com/science/article/ 
pii/0047637472900772?via\%3Dihub>. Accessed: Mar. 24, 2017. doi: 10.1016/0047-6374(72)90077-2.

NAIDOO, C. et al. The role of reactive oxygen species and antioxidants during pre-cooling stages of axis cryopreservation in recalcitrant Trichilia dregeana Sond. Botany, v.94, n.5, p.391-403, Mar. 2016. Available from: <http://www.nrcresearchpress.com/ doi/10.1139/cjb-2015-0248\#.XApqc9tKjIU>. Accessed: Dec. 05, 2018. doi: 10.1139/cjb-2015-0248.

OLIVEIRA, A. B. et al. Seed priming effects on growth, lipid peroxidation, and activity of ROS scavenging enzymes in $\mathrm{NaCl}$-stressed sorghum seedlings from aged seeds. Journal of Plant Interactions, Turim, v.11, n.4, p.1-9, Feb. 2011. Available from: $<$ https://www.tandfonline.com/doi/abs/10.1 080/17429145.2011.582590>. Accessed: Jul. 14, 2017. doi: $10.1080 / 17429145.2011 .582590$

PAMMENTER, N. W. et al. Viability of stored seed: extension by cathodic protection. Science, Washington, v.186, n.4169, p.1123 1124, Dec. 1974. Available from: <http://science.sciencemag.org/ content/186/4169/1123>. Accessed: May, 09, 2017. doi: 10.1126/ science.186.4169.1123

RABÊLO, L. A. et al. Redox Imbalance: NADPH oxidase as a therapeutic target in cardiovascular management. Arquivos Brasileiros de Cardiologia, São Paulo, v.94 n.5, p.684-693, Maio 2010. Available from: <http://www.scielo.br/scielo. php?script $=$ sci_arttext\&pid=S0066-782X2010000500018\&lng $=$ pt\&nrm=iso\&tlng=pt $>$. Accessed: Jun. 11, 2017. doi: 10.1590/ S0066-782X2010000500018.

RICALDONI, M. A. Ação antioxidante da água catódica: estudos preliminares em sementes de café, (Antioxidant action of cathodic water: preliminary studies on coffee seeds). 2016. $47 \mathrm{f}$. Dissertação (Mestrado em Fitotecnia) - Curso de Pós-Graduação em Fitotecnia, Universidade Federal de Lavras.

ROACH, T. et al. An oxidative burst of superoxide in embryonic axes of recalcitrant sweet chestnut seeds as induced by excision and desiccation. Physiologia Plantarum, Lund, v.133, n.2, p.131-
139, Jun. 2008. Available from: <https://onlinelibrary.wiley.com/ doi/abs/10.1111/j.1399-3054.2007.00986.x>. Accessed: Nov. 24, 2016. doi: 10.1111/j.1399-3054.2007.00986.x.

SAATH, R. et al. Activity of some isoenzymatic systems in stored coffee grains. Ciência e agrotecnologia. 38(1):15-24, 2014.

SHIRAHATA, S. Medical treatment and water, Oxygen-radical scavenging activity and inhibition of growth of cancer cells by electrolyzed-reduced water (in Japanese). In: Science and Application Technology of Functional Water (in Japanese), Water Science Association (Water Science Kenkyukai), Osaka, 1999, p.137-138. Available from: <https://www.jstage.jst.go.jp/ article/jhs/50/5/50_5_456/_article/-char/ja >. Accessed: Jun. 11, 2017. doi: $10.1248 / \bar{j}$ hs. $50 . \overline{4} 56$.

SHIRAHATA, S. et al. Electrolyzed-reduced water scavenges active oxygen species and protects DNA from oxidative damage. Biochemical and Biophysical Research Communications, Martinsried, v.234, n.1, p.269-274, May 1997. Available from: $<$ https://www.sciencedirect.com/science/article/pii/ S0006291X97966225?via\%3Dihub>. Accessed: May, 12 2017. doi: $10.1006 /$ bbrc. 1997.6622 .

TATONE, C. et al. Cryopreservation and oxidative stress in reproductive cells. Gynecological Endocrinology, London, v.26, n.8, p.563-567, Aug. 2010. Available from: <https:// www.tandfonline.com/doi/abs/10.3109/09513591003686 395? journalCode=igye20>. Accessed: Jul. 16, 2017. doi: $10.3109 / 09513591003686395$.

VERTUCCI, C. W.; FARRANT, J. M. Acquisition and loss of desiccation tolerance. In: KIGEL, J.; GALILI, G. (Eds.). Seed development and germination. New York: Basel-Hang Yong, 1995, p.237-271.

WHITAKER, C. et al. Production of reactive oxygen species in excised and cryopreserved explants of Trichilia dregeana Sond. South African Journal of Botany, Matieland, v.76, n.1, p.112118, Jan. 2010. Available from: $<$ https://www.sciencedirect.com/ science/article/pii/S0254629909002889?via\%3Dihub>. Accessed: Dec. 19, 2016. doi: 10.1016/j.sajb.2009.09.008. 